\title{
Isolated azygos vein thrombosis: a rare phenomenon
}

\author{
Yuan Hwen Liew, ${ }^{1}$ Sidney Ching Liang Ong, ${ }^{2}$ Viknesh Balasingam ${ }^{1}$
}

'Department of Diagnostic Imaging, Hospital Tuanku Ja'afar, Seremban, Negeri Sembilan, Malaysia

${ }^{2}$ Radiology Department, Clinical Campus, International Medical University, Seremban, Negeri Sembilan, Malaysia

\section{Correspondence to} Dr Sidney Ching Liang Ong, sidney_ong@yahoo.co.uk

Accepted 4 November 2017

\section{DESCRIPTION}

A 57-year-old man with diabetes mellitus and liver cirrhosis was electively admitted for endoscopic retrograde cholangiopancreatography (ERCP). He had history of obstructive jaundice secondary to choledocholithiasis in the preceding month, during which a biliary stent was inserted. During ERCP, he developed acute chest pain and shortness of breath. ECG, cardiac enzymes, coagulation profile and chest radiograph were normal. He was then suspected to have acute pulmonary embolism.

CT pulmonary angiography (CTPA) showed a central tubular filling defect within the azygos vein (AV). This filling defect has a small attachment at the roof of the vessel, forming acute angle with the vessel wall (figures 1 and 2). The rest of the pulmonary vasculature was fully opacified. Lung fields were normal.

No definite treatment was initiated, and the patient was kept in the ward for close observation. His symptoms resolved spontaneously, and he was discharged home well.

The AV drains deoxygenated blood from the posterior chest and abdominal walls. It is formed by the union of ascending lumbar veins and right subcostal veins at T12-L2 level. It typically passes through the aortic hiatus and ascends in the thorax to the right of the vertebrae before arches over the right main bronchus posteriorly to join the superior vena cava. Some associated normal variants are agenesis, azygos fissure and azygos continuation of the inferior vena cava.

Isolated AV thrombosis is a rare phenomenon. The pathophysiology of AV thrombosis is poorly understood but may be categorised into primary (unprovoked) and secondary (provoked). The few reported cases of AV thrombosis have identifiable predisposing factors such as existing AV aneurysms, peripherally inserted central catheter, Escherichia coli sepsis with underlying antiphospholipid syndrome and spinal epidural abscess. ${ }^{1-3}$ Our patient might have acquired $\mathrm{AV}$ thrombosis as a result of coagulopathy from

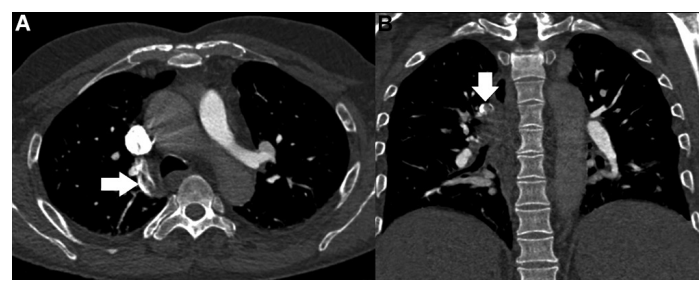

To cite: Liew YH, Ong SCL Balasingam V. BMJ Case Rep Published Online First: [please include Day Month Year]. doi:10.1136/bcr-2017222821

CrossMark
Figure 1 Selected axial (A) and coronal (B) sections of within the azygos vein (arrows). CT pulmonary angiography showing tubular filling defect

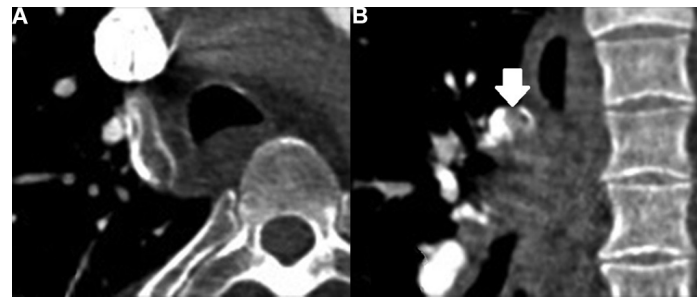

Figure 2 Collimated and enlarged axial (A) and coronal (B) sections from figure 1 showing the attachment of the tubular filling defect to the roof of the azygos vein forming acute angle (arrow).

underlying liver cirrhosis. Acute angle between the thrombus and vessel wall indicates an acute event.

Clinical relevance of identifying AV thrombosis lies in the risk of pulmonary embolism. Septic AV thrombus has been identified as a nidus for septic pulmonary embolism. ${ }^{1}$ If there is an intracardiac or intrapulmonary shunt, there is also a theoretical risk of paradoxical intracranial embolism, but this has not been proven before. Signs and symptoms of AV thrombosis are usually related to underlying causes or complication (pulmonary embolism). Treating (or removal) of the underlying cause will result in resolution of symptoms. In our case, however, it is unclear why he developed chest pain and shortness of breath because lung fields were normal on CTPA and there was no sign of right ventricular strain on ECG. Nevertheless, his symptoms resolved spontaneously and he is being followed up as outpatient.

If the $\mathrm{AV}$ is not visualised on routine CTPA, there is no indication to perform a dedicated CT scan protocol unless there is strong suspicion of AV thrombosis (misplaced catheter tip or azygos aneurysm). Management of $\mathrm{AV}$ thrombosis is tailored according to the predisposing factors. Possible measures include mechanical thrombectomy, vein filter, removal of central catheter, anticoagulant, antibiotic or mere supportive treatment.

\section{Learning points}

Isolated azygos vein thrombosis is a rare phenomenon.

- Pathophysiology and complications of azygos vein thrombosis are poorly understood.

- Management of azygos vein thrombosis should be tailored according to the predisposing factors. 
Contributors All authors have contributed sufficiently to the project and have met all criteria to be included as authors.

Competing interests None declared.

\section{Patient consent Obtained.}

Provenance and peer review Not commissioned; externally peer reviewed.

(c) BMJ Publishing Group Ltd (unless otherwise stated in the text of the article) 2017. All rights reserved. No commercial use is permitted unless otherwise expressly granted.

\section{REFERENCES}

1 Pradhan G, Shaheen K, Muoneka M, et al. Pulmonary septic amboli due to azygos vein thrombosis. Case Rep Med 2013:Article ID 904057.

2 Sherif MM, Hall R, Schauer CK. Azygos vein thrombosis secondary to a peripherally inserted central catheter (PICC). J Vasc Access 2015;16:e82-3.

3 Lee HJ, Kang YM, Lee E, et al. A Case of Azygos Vein Thombosis Associated with Transient Antiphospholipid Syndrome in Urinary Tract Infection with Escherichia coli. J Rheum Dis 2016;23:118-21.

Copyright 2017 BMJ Publishing Group. All rights reserved. For permission to reuse any of this content visit http://group.bmj.com/group/rights-licensing/permissions.

BMJ Case Report Fellows may re-use this article for personal use and teaching without any further permission.

Become a Fellow of BMJ Case Reports today and you can:

- Submit as many cases as you like

- Enjoy fast sympathetic peer review and rapid publication of accepted articles

- Access all the published articles

Re-use any of the published material for personal use and teaching without further permission

For information on Institutional Fellowships contact consortiasales@bmjgroup.com

Visit casereports.bmj.com for more articles like this and to become a Fellow 